\title{
Exploring the Role of the Wicked in Habakkuk from Malawi Socio-Economic and Political Viewpoint*
}

\author{
Takuze Saul Chitsulo (University of KwaZulu Natal)
}

\begin{abstract}
John Saul has qualified decolonisation in Southern Africa (19601990) as "false." This is true for Malawi because despite gaining independence in 1964, attaining multiparty democracy in 1994 and has had three presidents in the multiparty era, life for many Malawians continues to be a struggle for survival. This article seeks to explore the role of "the wicked" in the book of Habakkuk for purposes of letting the text dialogue with Malawi socio-economic and political context, which are both products of internal politics and external forms of imperialism. The theoretical framework relevant to this study is the African contextual biblical hermeneutics model. It is a tri-polar approach because it involves three poles: a) the African context; b) the biblical text; and c) appropriation. In this model, there is a two-way movement between text and context enabling each to interrogate the other critically, and constructing potential lines of connection. Since the study deals with the context of Habakkuk and the Malawi context, both of which are substantially shaped by social, economic and political conditions, liberation and postcolonial biblical hermeneutics will serve as the sub-theoretical frameworks. Within these theoretical frameworks, a sociological methodology will be used when analysing the biblical text and Malawi context.
\end{abstract}

Keywords: Habakkuk, the wicked, Malawi, politics, economies of extraction.

\section{A INTRODUCTION}

Malawi has been independent for fifty years now, however life for many Malawians is a struggle for survival. While there was clear attestation of decolonisation in 1964, it remains that it was without substance of liberation, especially in socio-economic terms, for those, the vast majority, at the bottom of social ladder in a freshly "liberated" Malawi. ${ }^{1}$ Malawi continues to be among

* To cite: Takuze S. Chitsulo, "Exploring the Role of the Wicked in Habakkuk from Malawi Socio-Economic and Political Viewpoint," OTE 28, no. 2 (2015): 301-325. DOI: http://dx.doi.org/10.17159/2312-3621/2015/v28n2a6

1 John S. Saul, Decolonization and Empire: Contesting the Rhetoric and Reality of Resubordination in Southern Africa and Beyond (Johannesburg: Wits University Press, 2008), 41. 
the ten poorest countries in the world. The state of affairs indicates that postcolonial Malawi deals with new face of colonialism that is capitalistically inclined. The situation shows that the struggle is not yet complete; the struggle for liberation and life continues. ${ }^{2}$ Under such struggles, questions that Habakkuk raised in ancient times (1:2-4) matter in our time. Habakkuk wrestled with the universal question "Why?" He posed it centuries ago, it is the very question that is asked in modern times, and no satisfactory answer has been given.

This paper seeks to react to the question why an exploration of the role of the wicked in Habakkuk is crucial to the understanding of Malawi socioeconomic and political context? The study belongs to postcolonial biblical studies - the meeting point of postcolonial studies and biblical studies. ${ }^{3}$ Postcolonial studies emerge from the reality of the actual lived experiences of particular forms of colonialism or imperialism. ${ }^{4}$ Equally, postcolonial biblical criticism is a terrain that centres on three things: issues surrounding political, cultural and economic colonial setting that produced the text; presentation of both biblical and modern empires and their impact; lastly, it focuses on the freedom of subjected nations. ${ }^{5}$ So, postcolonial biblical criticism is devoted to analysing an ancient biblical text in light of social, economic, cultural and political context that has been shaped by imperialism. The study deals with the biblical text of Habakkuk and the Malawian context considering that both contexts are products of internal and external forms of imperialism.

\section{B SOCIO-ECONOMIC AND POLITICAL ANALYSIS OF MALAWI}

Preaching at the national service of worship of 2001 Malawi Independence Day celebrations, the Anglican Bishop James Tengatenga saw no reason to celebrate considering the difficulties Malawians were facing at that time. He cited among other things, the economy that was collapsing; health system that lacked medicine; lowering of education standards; and a political scene that was threatening to impose a third term bill for a president running a second term in office. ${ }^{6}$ Alt-

2 Gerald O. West, Biblical Hermeneutics of Liberation: Modes of Reading the Bible in the South African Context Second Revised Edition, (Pietermaritzburg: Cluster Publications, 1995), 15; see also Musa W. Dube, "Toward a Post-Colonial Feminist Interpretation of the Bible," Semeia 78 (1997), 14.

Stephen D. Moore \& Fernando F. Segovia, eds. Postcolonial Biblical Criticism: Interdisciplinary Intersections (London: T \& T Clark International,2005), 2.

4 Gerald O. West, "Doing Postcolonial Biblical Interpretation @ Home: Ten Years of (South) African Ambivalence," Neotestamentica 42, no. 1 (2008), 152.

5 Rasiah S. Sugirtharajah, Exploring Postcolonial Biblical Criticism: History, Method, Practice (Chichester: Wiley-Blackwell, 2012), 2-3.

6 James Tengatenga, "Seek His Kingdom and His Righteousness and All Things Will Be Given to You," (Unpublished manuscript, 2001). Sermon preached at the Malawi National Independent Celebration Service of Worship, held in Mzuzu on 5 July 2001). 
hough his sentiments were not well-received among politicians who retorted with affronts, it remains that postcolonial Malawi suffers from manifold socioeconomic and political problems that retard development. The conditions affirm that Malawi has had a stormy socio-economic colonial and postcolonial history. $^{7}$

The main cause of these problems is economies of extraction - a particular form of capitalism that African states inherited upon gaining independence from colonial masters. Because we are concerned with why Malawi is still rated among the world's ten poorest countries despite being independent for 50 years, the article focuses on the postcolonial history of Malawi. There is a detailed discussion on this in my article, "The Bible and Socio-Economic Transformation in Malawi," where I have analyzed historically the role the Bible played in social transformation of Malawi from the missionary-colonial era to present day Malawi. As a way of locating the Malawian context in this study, I will briefly give the postcolonial history of Malawi before moving to an exploration of the wicked in Habakkuk.

\section{Postcolonial History of Malawi}

Thirty years of Malawi's postcolonial political course was dominated by Hastings Kamuzu Banda - the first Malawian president, who became a dictator immediately after taking over leadership from the colonial masters. ${ }^{8}$ Banda's tyrannical mechanism paved the way for him to rule Malawi with one party government. ${ }^{9}$ His rule was characterised by fear, social injustice and economic exploitation. It is no exaggeration to say that Malawi was a police state; wherever the people gathered, in a church, a tavern, at a wedding etcetera, there were police agents in plain clothes. ${ }^{10}$ In describing the era, Ross cites a report by a delegation of British lawyers who visited Malawi in 1992: "The emotion

7 John L. C. Lwanda, Music, Culture and Orature: Reading the Malawi Public Sphere, 1949-2006 (Zomba: Kachere Series, 2008), 7.

8 John McCracken, A History of Malawi 1859-1966 (Woodbridge, Suffolk: James Currey, 2012), 430; Desmond D. Phiri, History of Malawi Volume 2 (Blantyre College Publishing Company (Pvt) Ltd, 2010), 305.

9 Traits of Banda's dictatorship can be traced from 1960 when he was made life president of the Malawi Congress Party which meant that no one could contest his leadership in the party. In 1971, by Act of Parliament, Banda's Malawi Congress Party was made the only lawful party; only in exile did opposition parties exist. In the same year, he was declared life president of Malawi which meant that so long as he was alive no one could by constitutional means become or aspire to become president of Malawi. See Phiri, History 2, 305-308.

10 Phiri, History 2, 305. 
we encountered, among citizens at every level, from villages to government officials was fear."

Banda used capitalistically inclined principles that saw a few Malawians, mostly those close to him in the Malawi Congress Party elite, enriching themselves and leaving the majority of Malawians in dire poverty. The system supported a few people to own business that survived because government gave them contracts; certain government assets were sold cheaply to those in the patronage system. ${ }^{12}$ There was abuse of public funds at the expense of poor Malawians. ${ }^{13}$ Banda, a Chewa himself, encouraged tribalism that elevated his tribesmen above other tribes - a practice that threatened the social, economic and political life of Malawi. ${ }^{14}$ McCracken mentions that during the cabinet crisis, ministers accused Banda of favouritism and nepotism citing Tembo family and other ministers like Aleke Banda as the most favoured. ${ }^{15}$ Under such circumstances, nobody dared to confront Banda; anyone who challenged his authority was beaten, imprisoned, exiled or killed. Thus, Ross is correct to further describe Malawi at that time as a land where silence ruled. ${ }^{16}$

\section{The 1992-94 Political Change: Multiparty Era}

The seeds of hope for the long anticipated change were sown when Catholic Bishops in Malawi issued a pastoral letter "Living Our Faith," which was read in all Roman Catholic churches on 8th March 1992. In June 1992, Presbyterians joined the Bishops in criticising Banda's regime by presenting an open letter to president Banda entitled "The Nation of Malawi in Crisis: the Church's Concern." There is a full discussion on two letters in my article referred to above. The letters were the church's reaction against the social ills Malawians faced during Banda's regime. They also served as the initial stride towards political change that finally took place in 1994 that saw Malawi embracing a multiparty system of government. Despite gaining independence in 1964 and multiparty politics in 1994, Malawi continues to face numerous socio-economic problems affecting the majority poor. Since 1994, Malawi has witnessed four leaders ascending to power; but nothing has really changed in terms of

11 Kenneth R. Ross, "The Transformation of Power in Malawi 1992-95: The Role of the Christian Church," The Ecumenical Review 48, no. 1 (1996), 41.

12 John L. C. Lwanda, Kamuzu Banda of Malawi: A Study in Promise, Power and Ligacy (Malawi under Dr. Hastings Kamuzu Banda (1961-1994) (Zomba: Kachere Series, 2009), 395.

13 Lwanda, Катиzи Banda, 399. Lwanda refers to a trip Dr Banda and his entourage made to Britain that costed over a million dollars at the time the Malawian government was begging for aid.

14 Lwanda, Kamuzu Banda, 351.

15 McCracken, A History, 432.

16 Kenneth R. Ross, "The Transformation of Power in Malawi 1992-95: The Role of the Christian Church," The Ecumenical Review 48, no. 1 (1996), 38. 
governance. Politics of granting favours or giving contracts or making appointments to office in return for political support have persisted from Banda's regime to present.

The patronage and repression based rule of Banda (1964-1994) was replaced by the patronage and money based rule of Dr. Bakili Muluzi (19942004). ${ }^{17}$ Dr. Bingu wa Mutharika (2004-2012) adopted a stance that tries to mix elements of the two; mixing elements of recycled politicians from the Muluzi and Banda era despite an initial promise to break with the past. ${ }^{18}$ The use of recycled politicians that encourages the patronage system was also evident in Mrs. Joyce Banda's regime (April 2012 to May 2014) and continues in the current administration of Peter Mutharika. These trends have increased poverty, corruption, personality based parties and a failing economy in Malawi. The situation helps us understand why Saul has qualified the decolonization that took place in southern Africa between 1960 and 1990 as "false," suggesting that it did not go deep enough to demolish the foundations of colonialism.

It is perspicuous that postcolonial Malawi deals with a new face of colonialism known as economies of extraction - a form of capitalism inherited within Africa. The phrase denotes the idea of imperialism where imperial powers come into a context for purposes of extracting. They come in the name of aid, namely, build roads, hospitals, schools etcetera and in return they extract from poor countries' resources. On the local scene, it has been observed that many join politics not to help the people, but to enrich themselves. So, they join politics for the sole reason of extracting from the country's little resources meant to assist the poor. In economies of extraction, the external imperial power always has a lot of influence on the internal political will to the extent that those in power work collaboratively in creating most of Africa's socioeconomic problems. Thus, it is this neo-colonialism that cripples economic growth of Malawi.

The book of Habakkuk has been identified as a resource that can help us understand the Malawian context. As "a Pastoral Book," it speaks to some of the deepest needs of men and women who are oppressed and depressed by the ways of this world. ${ }^{19}$ The tone of the book reveals a socially, economically, politically and religiously dying nation. Judah of Habakkuk's time suffered terribly under the oppressor he calls "the wicked." The presence of the wicked threatened the normal order of Judean society. Their repressive ways forced Habakkuk to raise complaints to God. ${ }^{20}$ It is crucial, therefore, to investigate

17 Lwanda, Music, 7.

18 Lwanda, Music, 7.

19 Donald E. Gowan, The Triumph of Faith in Habakkuk (Atlanta: John Know Press, 1976), 9.

20 We prefer to refer to Habakkuk's prayers as "complaints" rather than "lament" because the latter is more suited to a prayer of misery appealing to God's pity, 
the situation of Habakkuk in order to establish how his message becomes a resource to Malawi. We shall now conduct a socio-historical analysis of the book of Habakkuk in order to unearth circumstances leading to Habakkuk's prophecy.

\section{SOCIO-HISTORICAL ANALYSIS OF THE BOOK OF HABAKKUK}

The main objective of this analysis is to unearth the historical and sociological world that lies behind the text and from which the text of Habakkuk comes from. ${ }^{21}$ Here, we are immensely concerned with the socio-economic and political life of the community that produced the text. There is a special correlation between the two since socio-economic life is always shaped by the political life. Therefore, our main task is to yield an economic reading of Habakkuk's situation, which was essentially conditioned by the religion and politics of ancient Israel. Religion and politics in ancient Israel were inseparable; when we assess the politics of ancient Israel, we are inevitably assessing its religious component as reported by the $\mathrm{HB}^{22}$ This entails that religion and politics together had a lot of influence on Israel's socio-economic life.

For us to understand the socio-economic and political milieu of Habakkuk, we need to be familiar with economic mechanisms involved at that particular time. These were means that a state used for its running. ${ }^{23}$ Succinctly, it is called political economy. It is the means by which people produce and reproduce their lives. ${ }^{24}$ Economic mechanisms of Habakkuk's time can be traced by analysing the wider framework in which ancient Israel belonged - the Ancient Near East (ANE). Roland Boer argues that one way of making sense of the ANE history is to study economics of the region, which he calls sacred economy. ${ }^{25}$ By sacred economy he means a system in which the economy operates and is

whereas a "complaint" can take the form of a protest and an appeal to God's justice from a person who has been victimised. See Francis I. Andersen, Habakkuk: A New Translation with Introduction and Commentary (New York: The Anchor Bible Doubleday, 2001), 21.

21 Gerald O. West, Contextual Bible Study (Pietermaritzburg: Cluster Publications, 1993), 27.

22 Norman K. Gottwald, The Politics of Ancient Israel (Louisville, Kentucky: Westminster John Knox Press, 2001), 3.

23 Sigmund Wagner-Tsukamoto, "State Formation in the Hebrew Bible: An Institutional Economic Perspective," Journal for the Study of the Old Testament 37 no. 4 (2013), 395.

24 Norman K. Gottwald, "From Tribal Existence to Empire: The Socio-Historical Content for the Rise of the Hebrew Prophets," in God and Capitalism: A Prophetic Critique of Market Economy, ed. J. Mark Thomas and Vern Visick (Madison, Wisconsin: A-R Editions, Inc, 1991), 12.

25 Roland Boer, "The Sacred Economy of Ancient "Israel"," Scandinavian Journal of the Old Testament 21, no. 1 (2007), 34. 
understood in terms of the sacred rather than the political. Gerald West calls this temple-state economy because at the base there is religion. ${ }^{26}$ This suggests that in the ANE, politics are shaped by religion. Because this study explores the role of the wicked in Habakkuk, we begin this analysis by discussing the identity of the wicked before dealing with economic systems that undergirded Habakkuk's message.

\section{WHO ARE “THE WICKED” IN HABAKKUK?}

Before answering this question, we need to understand that Habakkuk belongs to a unique corpus known in the OT as the Writing Prophets. These books Isaiah through Malachi - were written in response to the rise and fall of the Assyrian and Babylonian empires; ideally, they address the three key moments in Israel's history: the fall of Samaria in 722 B.C.E., the fall of Jerusalem in 587 B.C.E. and Cyrus' decree in 538 B.C.E.. ${ }^{27}$ This entails that Hebrew prophecy came about in wartime, and war is the subject of, or background to most prophetic books. ${ }^{28}$ Their message is inseparable from the empires which determined the history of the ANE and the fate of Israel and Judah from the eighth century to the end of the sixth century B.C.E.. ${ }^{29}$ This underlines the fact that Israel and Judah did not live in a vacuum. Even their prophets often spoke from the context of national and international awareness and insight. ${ }^{30}$ For us to understand Habakkuk's message, we must have knowledge of the national and international historical setting of Judah, because such is the composition of the prophecy. $^{31}$

The prophecy shows that Habakkuk lived in a situation where the wicked surrounded the righteous and a foreign power dominated internal operations of Judah. Injustice overwhelmed Judah; the law proved ineffective (1:4); and Habakkuk thought that God was unconcerned and not sensitive to the

26 Gerald West, "Tracking an Ancient near Eastern Economic System: The Tributary Mode of Production and the Temple-State," OTE 24/2 (2011), 520-1.

27 Donald E. Gowan, Theology of the Prophetic Books: The Death \& Resurrection of Israel (Louisville, Kentucky: Westminster John Knox Press, 1998), 9.

28 David Aberbach, Imperialism \& Biblical Prophecy 750 - 500 B.C.E. (New York: Routledge, 1993), $1 \& 6$. Aberbach understands prophetic message as representing the triumph of the spiritual empire over the mortal empire, of the invisible God, King of the universe, over the human king of the civilised world, of losers over victors, of moral ideas over military force.

29 Aberbach, Imperialism, 1. See also Musa W. Dube, "Reading for Decolonization (John 4:1-42)," Semeia 75(1996), 26-30, for a definition of imperialism that helps us understand the milieu in which Israel and Judah found themselves when these prophets sounded their message.

30 William P. Steeger, "A Socio-Historical Examination of Habakkuk 1-2" (PhD Dissertation, Southern Baptist Seminary, 1983), 16.

31 Steeger, "A Socio-Historical," 16. 
greed, theft, debauchery, extortion, embezzlement and idolatry that prevailed. ${ }^{32}$ The prophet is weary - weary with the world as it is; the whole life was rooted in and shaped by the experience of pain and suffering. ${ }^{33}$ It was a critical period in Israel's history believed to be a time of social, political and religious unrest. Habakkuk's complaint is straight, "the wicked surround the righteous" (1:4b), suggesting that the wicked were causative agents of Judah's problems. ${ }^{34}$ But who are the wicked in Habakkuk? Since the first two chapters have definite clues to the date and circumstances of the prophecy, the task of identifying the wicked will focus on the dialogue between God and Habakkuk (1:2-2:4) and the woe oracles (2:5-20). The task will also investigate how the woe oracles are used in Habakkuk and try to identify the oppressor in the woe oracles.

\section{$1 \quad$ "The wicked" in Habakkuk 1:2-2:4}

Three views emerge concerning the identity of the wicked in Habakkuk: some say they were a foreign power; others consider them to be within Judah among the Israelites themselves; the last interpretation says they represented both internal cruelty and foreign power (cf. 1:4; 1:13). Those claiming the oppressor to be a foreign power have produced three differing propositions. While most exegetes maintain the reading Chaldean (1:6) as the wicked, claiming that the oppressor is the same throughout Habakkuk, others hold that the oppressor is neither the Chaldeans nor a class in the Jewish society but Assyrians. ${ }^{35}$ The scheme is that Assyria is the instrument of God's judgment against His people, an idea found in Isaiah 10:5. ${ }^{36}$ Based on Pharaoh Neco's killing of King Josiah at Megiddo in 609 B.C.E., another group suggests that Egypt is the oppressor in

32 Carol J. Dempsey, The Prophets: A Liberation-Critical Reading (Minneapolis: Fortress Press, 2000), 77.

33 Elizabeth Achtemeier, Interpretation Nahum - Malachi: A Bible Commentary for Teaching and Preaching (Atlanta: John Knox Press, 1986), 36.

34 In Habakkuk, the wicked are held responsible for the suffering of "the righteous" a small group of Judeans who were faithful to God's will, but not the whole nation of Israel. They may also have been the worshipping community at the Jerusalem Temple (Habakkuk's audience). Others have considered "the righteous" to be God's people in Judah under the leadership of the rightful ruler - Jehoahaz. See Steeger, Socio-Historical, 180, cf. 2 Kgs 23:28-37; 2 Chr 35:20-36:10).

35 Karl Von Budde, one of the proponents of this view, interprets Habakkuk 1:6 as a future reality, claiming that the Chaldeans cannot be regarded as in any sense the subject or occasion of the prophecy; but they are simply the instruments in Yahweh's hands for the achievement of his purpose, the bringing down of the oppressor, the release of his righteous ones, and ultimately the rescue of all the nations whom the oppressor had enslaved (see Andersen, Habakkuk, 24).

36 Andersen, Habakkuk, 24. 
Habakkuk. ${ }^{37}$ The two views were rejected because Assyria and Egypt are not mentioned in the book of Habakkuk. ${ }^{38}$

Those who claim that the oppressor is in Judah base their argument on the mention of "the law becomes slack" in 1:4. Their understanding is that the situation is in Judah because there was no nation in the biblical times that was given the law apart from Israel. Thus, they read the complaint of 1:2-4 as referring to internal injustice inflicted by powerful and wicked Judean leaders on their fellow citizens. ${ }^{39}$ Although some have placed Habakkuk during the reign of Josiah (640-609) and others during the closing days of the reign of Manasseh (686-642), the majority consider Habakkuk's message as a reaction to the abuses perpetrated in Judah during the reign of Jehoiakim ( $2 \mathrm{Kgs} 23: 34-24: 6){ }^{40}$ The views that located Habakkuk during the reigns of Josiah and Manasseh were rejected by many, as the moral conditions of Hab 1:2-4 are conflicting with the period of Josiah's reforms and the reforms Manasseh instituted in the latter part of his reign (2 Chr 33:15-16). ${ }^{41}$

The third view holds that the wicked in Habakkuk represented both internal cruelty and foreign oppression. The majority of scholars agree that Jehoiakim and officials at the king's court were internal oppressors, whereas Assyrians and Babylonians are largely accepted as external power. While the identification of Jehoiakim and his royal court as internal oppressors is plausible and supported by many, Aron Pinker suggests another possible oppressor by pushing the prophecy to the reign of Zedekiah. He argues that Habakkuk's advice in 2:4 was originally a political observation, rather than a moral or ethical paradigm as it is mostly claimed. ${ }^{42}$ After a thorough analysis of Hebrew word צ'ציק "righteous" in 2:4, Pinker concludes that Habakkuk's original text

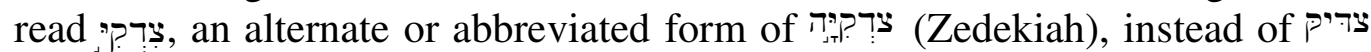
(righteous). ${ }^{43}$ To substantiate his argument, Pinker says:

37 George. A. Smith, The Book of the Twelve Prophets, Vol. 2. (New York: Harper \& Brothers Publishers, 1929), 124.

38 See Andersen, Habakkuk, 24, who says that there is nothing in the book of Habakkuk itself to identify Assyria as the wicked.

39 Rex. Mason, Zephaniah, Habakkuk, and Joel: Old Testament Guides (England: Sheffield Academic Press, 1994), 66.

40 Gowan, Theology of Prophetic Books, 92.

41 Hobart E. Freeman, An Introduction to the Old Testament Prophets. (Chicago: Moody Press 1968), 253-254, argues that the phrase "in your days" (1:5) would seem to disagree with prophetess Huldah's prophecy, in which she predicted that the calamity (described in Habakkuk) would not fall upon Judah in the lifetime of Josiah (2 Kgs 22:14-20).

42 Aron Pinker, "Habakkuk 2.4: An Ethical Paradigm or a Political Observation?," Journal for the Study of the Old Testament 32, no. 1 (2007), 102.

43 Pinker, "Habakkuk 2:4," 102. 
It is very easy to see why a scribe, well removed from Zedekiah's

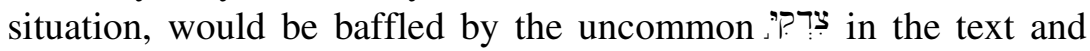
would correct it to the 'seemingly' more logical Indeed, it is even possible to argue that Zedekiah's rebellion against Babylon was an embarrassment for the exiled (Ezek. 17:12-22; Jer. 38:19) and was intentionally removed by a simple transposition of two letters. Finally, it is generally recognized that the current text is in most parts the result of various redactional activities, which aimed at projecting prophetic claims onto new generations. It is very likely that redactors felt free to expand and rewrite sections of a prophet's writings, believing that they articulated what the prophet would have said were he confronted with the problems of their own time. ${ }^{44}$

In this way, Pinker read the prophecy to mean that Habakkuk was advising Zedekiah the king of Judah that his personal survival depended on being steadfast in his loyalty to Babylon. ${ }^{45}$ He considers this kind of reading to be in line with Jeremiah's promise to Zedekiah that he will survive by being subservient to Babylon (Jer 27:12,17); the phrase "live by their faith" in 2:4 is similar to Jeremiah's advocacy that Zedekiah will live if he only surrenders to the Babylonians (Jer 38:17, 20). ${ }^{46}$

In this sense, it remains that the identification of the oppressor proposes that Habakkuk's prophecy was influenced by the political atmosphere taking shape in the ANE region around late seventh or early sixth century B.C.E.. The period saw the collapse of the Assyrian empire and the subsequent powerstruggle between the rising Babylon and Egypt over inheriting the territories spreading from the Euphrates to Sinai, which were abandoned by Assyria. ${ }^{47} \mathrm{We}$ notice that Judah had been a captive nation of Assyrian hegemony from the reigns of Manasseh (about 696-641 B.C.E.) to Josiah (639-609 B.C.E.). ${ }^{48}$ As Assyrian domination receded in Judah and elsewhere towards the end of Assurbanipal around 627 B.C.E., about the same time the Chaldeans were gaining momentum to the effect that they established their independent empire called Neo-Babylonian Empire. ${ }^{49}$ The fall of Kalakh and Nineveh in 612 B.C.E. were the ultimate signs that the Assyrian Empire ceased to exist. ${ }^{50}$ The new political situation in Babylon led to an alliance of Egypt and Assyria aimed at countering the new rival to both - the Neo-Babylonian State of the Chaldeans;

\footnotetext{
44 Pinker, "Habakkuk 2:4," 103-4.

45 Pinker, "Habakkuk 2:4," 102.

46 Pinker, "Habakkuk 2:4," 104.

47 Aron Pinker, Habakkuk: A Commentary (Unpublished manuscript, 2015).

48 Frederick F. Bruce, "Habakkuk," in The Minor Prophets: An Exegetical and Expository Commentary Vol.2, ed. Thomas E. McComiskey (Grand Rapids, MI: Baker Books, 1993), 833.

49 See Bruce, "Habakkuk," 833, and Freeman, Introduction, 256.

50 Pinker, Habakkuk.
} 
in essence, this was a contention between Babylon and Egypt vying for control of Syria and the Land of Israel. ${ }^{51}$

Pinker observes that Josiah, king of Judah, took advantage of the collapse of Assyrian power for territorial expansion and religious rejuvenation. ${ }^{52}$ Judah had a few moments to breathe, a few years without tribute; it was time to nourish new hopes of becoming an independent nation again under their able king, Josiah. ${ }^{53}$ Gowan describes Josiah's reforms as "a vain hope, for soon Egypt moved into the power vacuum left by Assyria's demise and briefly took control of Judah until the great Nebuchadnezzar came to power in Babylonia and was able to devote his attentions on the west." ${ }^{, 54}$ When Josiah was killed at Megiddo in 609 B.C.E., the people appointed Jehoahaz to replace his father; however, since Judah was made a vassal of Egypt, Neco exiled Jehoahaz to Egypt and installed a puppet Eliakim (whose name was changed to Jehoiakim) as king of Judah (2 Chr 35:20-25; 2 Kgs 23:29, 31-37). Egypt was defeated by Babylon in 605 B.C.E. and according to $2 \mathrm{Kgs} 24: 1$, Judah became a vassal state of Babylon when Jehoiakim surrendered and paid tribute to his new lord.

Barker mentions that of all Judah's evil kings, only of Jehoiakim is reported to have killed a prophet (Jer 26:20-23). ${ }^{55}$ Jeremiah, Habakkuk's contemporary, knew Jehoiakim as a ruthless and merciless ruler, who had cut up the scroll Jeremiah prepared and threatened the lives of Jeremiah and his scribe, Baruch (Jer 36:20-26). Jehoiakim died during the Babylonian siege of Jerusalem in 597 B.C.E. ${ }^{56}$ Jehoiachin his son succeeded him and ruled Judah for three months and ten days; Nebuchadnezzar appointed Zedekiah, Jehoiachin's uncle, as king over Judah (2 Chr 36:9-10). In 587/586 B.C.E., when Jerusalem was completely destroyed and many Judeans along with temple treasure, were forced into "Babylonian exile," Zedekiah was brought before Nebuchadnezzar at Riblah, where his children were slain before him and his eyes blinded. ${ }^{57}$ In a nutshell, this will be considered the political framework behind Habakkuk's message. Habakkuk depicts a time after Nineveh had fallen (612 B.C.E.), but before the first Babylonian invasion of Judah in 605 B.C.E. (2 Kgs 24). ${ }^{58}$ His prophecy came at the time when Nebuchadnezzar was threatening the freedom of Judah, namely, late in the seventh or early in the sixth century. The background of Jehoiakim's reign and the appearance of the Babylo-

\footnotetext{
51 Pinker, Habakkuk.

52 Pinker, Habakkuk.

53 Gowan, Triumph, 16.

54 Gowan, Triumph, 16.

55 Kenneth L. Barker and Waylon Bailey, Micah, Nahum, Habakkuk, Zephaniah (NAC 20; Nashville: Broadman \& Holman Publishers, 1998), 297.

56 Pinker, Habakkuk.

57 Pinker, Habakkuk.

58 Freeman, Introduction, 253.
} 
nian army under Nebuchadnezzar in Palestine/Syria supports the anguish of Habakkuk (608-598 B.C.E.; 2 Kgs 23:34-24:6).

\section{2 "The Wicked" in the Woe-Oracles of Habakkuk}

While we are able to identify the wicked in the first section, the second section (2:5-20) does not explicitly mark the oppressor. Habakkuk 2:5-20 is a poem introduced as a taunt against some unnamed oppressor by the peoples and nations which he had enslaved. It is this anonymity that makes this passage crucial for this study; its position in Habakkuk necessitates special treatment. Other interpreters consider it a kind of interlude between the really meaningful materials in ch. one and three, which has led them to say that the book is a product of many authors. ${ }^{59}$ In reaction, Szeles says: "What is conspicuous, however, is not the unity of its form but of its contents, for that fuses together all the separate parts." 60 This means the woe-oracles are part of the story Habakkuk is narrating in his book.

A series of five distinct oracles of woe begin in 2:6a with a call for everyone to taunt the oppressor. Marvin Sweeney observes that the form of the rhetorical question of course actually constitutes an assertion that everyone should indeed engage in such ridicule against the oppressor. ${ }^{61}$ Each oracle has a specific focus that describes the crimes perpetrated by the oppressor and the different responses to them. The first is directed towards those who obtain goods dishonestly (2:6b-8). It accuses the oppressor of greed and plundering that which is not her own. The second deals with building fortunes and power structures on unjust gain (2:9-11). Baker says that the oracle condemns not only exploitation for personal gain, but also for national or dynastic overdoing because the oppressor established his dynasty firmly by means of force and cunning. 62

The third oracle is the doom of evil and violence (2:12-14). It accuses the oppressor of bloodshed. Baker states that the very foundations of the centres of society were founded on bloodshed (cf. v.8; Nah 3:1, especially referring to Nineveh; Mic 3:10, to Jerusalem) and wickedness (cf. Isa 59:3; Mic 3:10). ${ }^{63}$ The fourth oracle is a woe against debauchery; it indicts the oppressor for terrible treatment of the subjugated nations (2:15-17). The world conqueror is now condemned for leading others, her neighbours, into wickedness by

59 Gowan, Triumph, 51.

60 Maria E. Szeles, Wrath and Mercy: A Commentary on the Books of Habakkuk and Zephaniah (Grand Rapids: Wm. B. Eerdmans Publishing Company, 1987), 7.

61 Marvin A. Sweeney, The Twelve Prophets: Studies in Hebrew Narrative \& Poetry, Vol. Two (Collegeville, MN: The Liturgy Press, 2000), 473.

62 David W. Baker, Nahum, Habakkuk and Zephaniah: An Introduction and Commentary (Downers Grove, IL: Inter-Varsity Press, 1988), 64.

63 Baker, Nahum, 65. 
causing them to drink intoxicants. The fifth woe is the doom of idolatry $(2: 18$ 20). This oracle points to the oppressor's idolatry and failure to recognise Yahweh (cf. 1:11, 16;2:13a) as the root cause for the atrocities outlined in this taunt song. ${ }^{64}$ The oppressor seeks her own security not only through violence and plunder, but also through resorting to powerless idols. This series of woes is designed to show that ultimately all sins listed in the woe oracles are doomed to destruction.

\section{The Use of Woe Oracles in Habakkuk}

Most of the uses of the word "woe" (הויhoy) in the prophets convey connotations of a curse, and it is true that there is no indication of grief in some of them, but frequently enough they appear in contexts of death and lamentation (Jer 22:18; 30:7; 34:5). ${ }^{65}$ In addition, the word hoy shows that the action under prophetic condemnation has seeds of death within it. ${ }^{66}$ Because of this, the majority of scholars embrace Hab 2:6-20 as a funeral song sung not for the oppressed but for the oppressor; the woe oracles are a taunt funeral song meant to ridicule the oppressor. ${ }^{67}$ In Habakkuk, the emotion is clearly joy because a tyrant is dead (2:10). ${ }^{68}$ Judah is not mourning the impending fall of her overlord, but uses the literary form of a funeral song to mock her. Habakkuk may be seen as using the language and themes of a funeral song, but for a brutal new purpose; God is sanctioning a suffering people to sing a mock funeral song in advance over the tyrant who has oppressed them. ${ }^{69}$ The prophet celebrates in

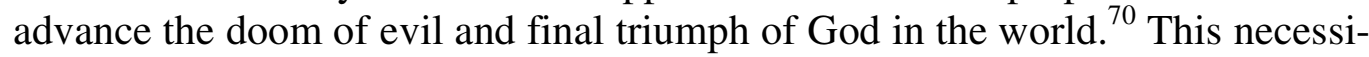
tates that all subjugated nations, whom the oppressor has persecuted, shall mock their conqueror.

\section{To Whom Does the Mock Funeral Song Apply?}

When one starts reading Hab 2:6-20, questions arise concerning against whom the woes are marked for and who the scoffer is. Tradition says Babylon is the world conqueror being mocked here. Evidently Habakkuk is the speaker on behalf of all subjugated peoples and nations. Here, the mock funeral song is placed creatively and unexpectedly in the mouths of the nations who had suffered from the unrestrained actions of Babylon. ${ }^{71}$ The song speaks of those who

\footnotetext{
64 Sweeney, Twelve 2, 477.

65 Gowan, Theology of the Prophetic Books, 96.

66 Barker and Bailey, Micah, 330.

67 See Gowan, Theology of the Prophetic Books, 96 and Szeles, Wrath and Mercy, 35-36.

68 Gowan, Theology of the Prophetic Books, 96.

69 Gowan, Theology of the Prophetic Books, 96.

70 Donald A. Leggett, Loving God and Disturbing Men: Preaching from the Prophets (Grand Rapids: Baker Book House, 1990), 105.

71 Barker and Bailey, Micah, 329.
} 
wrongfully enrich themselves, have plundered many nations, live in luxury and security at the expense of the poor, make use of liquor to shame their neighbours, and of worshippers of idols. ${ }^{72}$ While tradition accepts Babylon as the oppressor, Gowan and Leggett have differing views based on the fact that the text does not clearly mark the oppressor. Gowan argues that although in the context an application to the Babylonian oppressors is logical, the problem we have is lack of definite historical references in the woe oracles. ${ }^{73}$

Gowan identifies the oppressor by going back to v. 5. He says, "It has spoken of one whose greed is as wide as Sheol, who gathers for himself all nations, i.e. it is an apparent reference to a world-conqueror and his captive peoples." ${ }^{, 74}$ The significance of v. 5 is that it works as a transition between Hab 1:2-2:4 and the woe oracles; the woes are left without any identification of subject or singer without this verse. This demonstrates that v. 5 forms the prelude to a series of five woes pronounced on the oppressor by those whom he has brought under his yoke. Leggett suggests that the absence of specific historical references confirms that Habakkuk was condemning the sinful principles of life common to oppressors in every generation. ${ }^{75}$ Gowan agrees, he says what is described in woe oracles has occurred over and over again, and not only in antiquity. ${ }^{76}$ He further says no effort has been made in this song to refer to any specific situation in history; rather that it has purposely been expressed in general terms which could apply again and again to tyranny in many forms. Habakkuk did this deliberately because his concerns went far beyond the problems of Judah early in the sixth century, catastrophic though they were. ${ }^{77}$ Thus, Habakkuk produced a prophecy that could be used to apply to more than one situation.

\section{E ECONOMIC SYSTEMS USED IN HABAKKUK'S TIME}

When analysing ANE economic systems, special attention is paid to the modes of production that supported the systems. West identifies "household" and "tributary" modes of production as economic systems that undergirded biblical societies. ${ }^{78}$ He says that the two, together with the slave-based mode of production (relevant mainly to the economic world behind the NT) provide a most effective large scale historical framework for the Bible. Here, the focus is on the two modes of production, household and tributary, because they are crucial to understanding the socio-economic and political milieu of Habakkuk. The household or communitarian mode of production was dominant in the early

72 Gowan, Triumph, 57.

Gowan, Triumph, 57.

Gowan, Triumph, 52.

Leggett, Loving God, 105.

Gowan, Triumph, 57.

Gowan, Triumph, 57-58.

West, "Tracking," 513. 
Israelite settlements in Canaan, while the tributary mode of production was introduced when Israel turned to monarchy.

\section{F THE "HOUSEHOLD" OR "COMMUNITARIAN" MODE OF PRODUCTION}

Wagner-Tsukamoto argues that the formation of the Israelite state was legitimised on economic grounds. ${ }^{79}$ The people of Israel were not united when they first appeared in Canaan; they were only united for economic reasons. ${ }^{80}$ This argument is based on the fact that the fertile land in the Jordan Valley was considered a scarce commodity among both the Israelite tribes and other nations who made claims to the Promised Land, or neighbours to the Promised Land. Subsequently, the tribes of Israel ignored their differences and in one spirit acquired the land, and distributed it amongst themselves. The first Israelites in Canaan were residents of small villages, banded together in large families and tribes to protect themselves from the Canaanite city-states and ultimately from the Egyptian empire. ${ }^{81}$ They settled in the hill country of western Palestine and it was in these early settlements that we notice the development of modes of production.

Boer calls this "the village commune" because it was founded on kinship, and because it relied on its own means of production: family-owned lands and flocks of sheep and goats, it was considered to be an economic unit. ${ }^{82}$ There was something unusual about the first Israelite communities in that they did not give or take tribute; they refused allegiance to the states that taxed and conscripted their subjects, and they themselves strove not to extract tribute from one another. ${ }^{83}$ The household mode of production encouraged distinctive measures of self-help, cooperative labour, and mutual aid, extending assistance from one family or clan to another, making grants-in-aid that passed among the people without interest charges. ${ }^{84}$ Because the Israelites belonged to Yahweh, they were not willing to pay taxes, to be constricted into the city-state armies, or to be debt-obligated; they asserted the full and free use of their own labor products. $^{85}$

79 Wagner-Tsukamoto, "State Formation," 399.

80 Norman K. Gottwald, The Tribes of Yahweh: A Sociology of the Religion of Liberated Israel, 1250-1050 B.C.E. (Maryknoll, N.Y.: SCM Press Ltd., 1979), 32. See also Wagner-Tsukamoto, "State Formation," 402.

81 Gottwald, "From Tribal Existence," 14.

82 Boer, "Sacred Economy," 35.

83 Gottwald, "From Tribal Existence," 14.

84 Gottwald, "From Tribal Existence," 14.

85 Gottwald, "From Tribal Existence," 14. 


\section{G THE TRIBUTARY MODE OF PRODUCTION (TMOP)}

The communitarian mode of production did not prevail once Israel itself became a monarchic state with its own kings; power struggle within the tribes probably weakened the communitarian manner of life. ${ }^{86}$ Although this was the case, the communitarian spirit and practice of the people did not disappear overnight, but now it was dominated and threatened by Israelite state power under David and Solomon. ${ }^{87}$ The rise of Israelite monarchy meant that tribes of Israel were now moving towards a system - tributary mode of production they had opposed when they first arrived in Canaan. The shift also meant that the Israelites were now able to be ruled and oppressed by Israelite kings, merchants and landlords instead of by non-Israelites. ${ }^{88}$ It was this turn to monarchy that set the stage for Israel's prophets to appear. ${ }^{89}$ In agreement, J. Mark Thomas says prophets in ancient Israel arose mainly in opposition to economic systems that were forced on the people and were exploitive. ${ }^{90}$ He claims that the role of the prophets was to apply the "communitarian" ethic of the underclass to a prosperous kingship which had returned to conscription and exploitation. $^{91}$

In effect, the prophets arose in opposition to the TMoP. This form of production included relationships of domination, wherein a powerful state (such as Egypt, Assyria, or Babylon) or a smaller city-state (such as Canaan or Syria) dominated a considerable stretch of land made up largely of villages engaged in agriculture and animal breeding. ${ }^{92}$ West agrees that the TMoP was characteristic of imperial political economies in the ANE. ${ }^{93}$ Although he focuses on the biblical history between two texts, 1 Sam 8 and Mark 12, West claims that this economic system has endured from ancient times to the present. ${ }^{94}$ To these claims, Gottwald cited Marx who indicated that when British capitalism penetrated China and India, it found intact a traditional form of political econ-

\footnotetext{
86 Gottwald, "From Tribal Existence," 16.

87 Gottwald, "From Tribal Existence," 16.

88 Gottwald, "From Tribal Existence," 16.

89 Gottwald, "From Tribal Existence," 16.

90 J. Mark Thomas, "The Quest for Economic Justice" in God and Capitalism: A Prophetic Critique of Market Economy, ed. J. Mark Thomas and Vern Visick (Madison, Wisconsin: A-R Editions, Inc, 1991), 6-7.

91 Thomas, "The Quest," 7.

92 Gottwald, "From Tribal Existence," 16.

93 West, "Tracking," 512.

94 West, "Tracking," 512.
} 
omy that had persisted from antiquity. ${ }^{95}$ This has led many to describe TMoP as pre-capitalist.

West regards 1 Sam 8 as "birth" narrative of the TMoP because it deals at narrative level with the mechanisms by which the emerging political economy would operate. ${ }^{96}$ The text outlines the socio-economic cost of a city-state (vv. 11-18); for there can be no city-state without mechanisms of economic extraction. ${ }^{97}$ Economic extraction denotes a process of extracting something from a producer by someone or some group that has not produced it; it is exploitive as it involves those who do not labour gaining from those who labour. ${ }^{98}$ In the TMoP, economies of extraction involved a local state extracting from the peasants and an imperial power extracting from subject states and tribute was the main form of exploitation. ${ }^{99}$ Peasants had "use ownership" of the land, but the state claimed entitlement to tax the villages first in the form of payment in kind and second in the form of conscription of labour for public works or army service; which meant that the state regularly intruded into the village communities and took a good part of their labour products. ${ }^{100}$

Many peasants, already living on the margin, were further impoverished and driven into debt by these measures. ${ }^{101}$ The tributary social system was precapitalist because a strong state and the upper classes dominated the majority of people through taxes, rents and debts. ${ }^{102}$ The TMoP came to maturity during Solomon's reign when large scale public works, particularly the building of the temple (1 Kgs 6-9), extravagance of "normal" court life (1 Kgs 4:22-28), and maintenance of the security of the state, increased the need for tribute and forced labour. ${ }^{103}$ The situation made Israel to move from a political economy in which wealth was the product of diligent work and therefore a blessing from God, to a political economy in which wealth was the product of the oppression of the poor. ${ }^{104}$ Thus, West is right to say that "the rich" were wealthy because "the poor" were poor, for he observes that the primary systemic mechanism that linked the rich and the poor was tribute induced debt. ${ }^{105}$

95 Norman K. Gottwald, "Early Israel and the Canaanite Socio-Economic System," in Palestine in Transition: The Emergence of Ancient Israel, ed. David N. Freedman and David F. Graf (Sheffield: The Almond Press, 1983), 26.

96 West, "Tracking," 514-515.

97 West, “Tracking," 515.

98 Boer, "Sacred Economy," 39.

99 Boer, "Sacred Economy," 41.

100 Gottwald, "From Tribal Existence," 13.

101 Gottwald, "From Tribal Existence," 13.

102 Gottwald, "From Tribal Existence," 13.

103 West, "Tracking," 516.

104 West, "Tracking," 516.

105 West, “Tracking," 516. 
Although the Judean economy in Habakkuk's period is practically unknown and any efforts to deduce economic systems that were used at that time could be hypothetical, we can still conclude that Habakkuk's message fits within the TMoP, which was the dominant economic system in Judah of his time. The wicked in Habakkuk, therefore, can be located as operating within this framework. The anguish of Habakkuk stems from oppressive and exploitive economic measures set by the Judahite elite in alliance with their foreign oppressors. In describing the partnership involved, Gifford says the local leaders became brokers between their own community and central government, passing benefits in both directions, and probably taking their share in the process. ${ }^{106}$ Thus, Jehoiakim and his officials extracted surpluses from the poor Judeans through taxes, rents and debts that were imposed on the people in order to meet the demands made by their foreign oppressors. Strangely, as in all other states in ANE, this exploitive economic system was legitimated by Israelite religion and the temple became the economic hub of Israelite nation as shown in the subsequent discussion.

\section{The Role of the Temple in Ancient Israel}

The present discussion helps us to understand how the city or state in the ANE is unthinkable without the structuring role of the temple and indeed the palace which is an add-on to the temple. In the ANE, the temple functioned both as a centralised place of worship and as a centre for the collection and distribution of agricultural goods. ${ }^{107}$ It was also used as a centre for collecting tribute from conquered states and villages within the boundaries of the state in power. The primary role of tribute was the maintenance of the temple-city complex and the large imperial state. ${ }^{108} \mathrm{We}$ understand the temple-city complex as the nucleus of the state formed out of exploitation. ${ }^{109}$ The term is self-descriptive, for it designates the way the city or state is inconceivable without the temple. The temple became the central institution that made the system work.

The ANE temples were understood as economic hubs for their nations. In Egypt, during the empire period (1540-1100 B.C.E.), temples became very wealthy through booty, tribute and donation of large estates so that they were

106 Paul Gifford, African Christianity: Its Public Role (London: Hurst \& Company, 1998), 6.

107 Marc Van De Mieroop, A History of the Ancient near East, Ca. 3000-323 Bc, Second Edition (Malden, MA: Blackwell Publishing, 2007), 16.

108 Boer, "Sacred Economy," 41.

109 Gösta W. Ahlstrom, Royal Administration and Nataional Religion in Ancient Palestine (Leiden: E. J. Brill, 1982), 5. Boer, "Sacred Economy," 36, points out that the temple-city complex is not the same as the state; rather, the state arises in a tension between the village commune and the temple-city complex. Thus, the state provides the required security or authority that assists the temple-city complex to extract from villages within the boundaries of the state. 
repositories for the revenue of the empire. ${ }^{110}$ Also, in providing education, temples produced and sustained the professional class, including astronomers, doctors, scribes, and singers, most of whom were priests. ${ }^{111}$ The Mesopotamian temples of Uruk, Sumer and Girsu were very rich and prosperous having abundant resources in livestock and agricultural products; but the Babylonian temples constituted the richest agricultural, industrial and commercial units within the society. ${ }^{112}$ For this reason, temples in the ANE were dominated by kings even if they did not emerge from the temple hierarchy themselves. ${ }^{113}$ The Jerusalem Temple economic system was designed following the pattern of other ANE temples.

The Jerusalem temple stood side by side with the palace and the king controlled the priesthood, thereby affirming that religion and politics in ancient Israel were inseparable. ${ }^{114}$ There was only a theoretical distinction between the national and religious treasuries, with the king exercising total control of the temple treasury. ${ }^{115}$ The state legitimated the tax-rent as payment due to Yahweh's servants who protected the patrimonies of the free agrarians; thus, the state extraction of surplus was religiously rationalised by the ruling class in monarchic Israel and Judah. ${ }^{116}$

The ideology that tribute was justified and sanctioned by Yahweh played a significant role in the creation of the tributary system in ancient Israel. For that reason, the temple in ancient Israel was not only a worshipping centre; it also played a crucial role in sustainable economic growth of Israel. The role of the temple in formal education ensured the ideological legitimation of its economic dimensions among the ruling elite; which in turn played a part in the legitimation of the temples' role in economic extraction. ${ }^{117}$ This implies that continuity in economic extraction was guaranteed through education offered at the temple that targeted the elite only. All activities at the temple were organised to serve as tools of economic extraction.

110 West, "Tracking," 521.

111 West, "Tracking," 521, adds that the temples provided a site and sustenance for sectors of the merchant class for Egyptian temples were involved in trade, including the selling of meat, wine, and cakes.

112 West, "Tracking," 522.

113 Daniel C. Snell, Life in the Ancient near East, 3100-332 B.C.E. (New Haven: Yale University Press, 1997), 18.

114 West, "Tracking," 524.

115 West, "Tracking," 524.

116 West, "Tracking," 520. By state, we mean the ruling class in monarchic Israel and Judah.

117 West, “Tracking," 522. 


\section{H READING HABAKKUK FROM MALAWI SOCIO-ECONOMIC POLITICAL VIEWPOINT}

Based on this analysis, we can conclusively say king Jehoiakim and his officials together with their external oppressors collaborated in creating atrocities outlined in Hab 3:17. Judah's economy depended on three main fruit crops that they ate - figs, grapes and olives; fields that yielded barley and wheat; and the common domestic animals - sheep, goats and cattle. ${ }^{118}$ The six clauses in 3:17 appear to be in ascending order of severity, loss of figs ranking least and loss of the herd in the stalls causing the greatest economic damage; together, the losses spelled economic disaster and devastation loss of hope. ${ }^{119}$ Certainly drought is not behind these conditions since Habakkuk does not provide any portentous clues that there was famine in Judah of his time.

Greg Woolf's definition of empires helps us understand how the elite in Judah, acting as agents between their subjects and the empire (external oppressors), benefited from the system. He says:

Empires are political systems based on the actual or threatened use of force to extract surpluses from their subjects. Imperial elites spend these revenues on the infrastructure necessary to maintain power, and retain a profit that is distributed to groups that are privileged by virtue of their place within the imperial hierarchy. ${ }^{120}$

Boer calls the role played by the elite in Judah mediations since the elite at the city-state or city complex stood between despotic empire and village commune. ${ }^{121}$ Thus, they were able to extract from their subjects (mostly poor people) in order to meet the demands made by the empire. In the process, the king and those close to him benefited from the system since not everything extracted from the people reached the despotic empire. Thus, the majority poor were getting poorer and poorer while the elite few were getting richer and richer.

This is crucial for understanding economies of extraction in Malawi. We observe that economies of extraction are a useful link between economic dimensions of Habakkuk and those of Malawi. The socio-economic and political analysis of Malawi revealed that from 1964 to 1994 politics posed as a threat to the socio-economic development of Malawi. The switch to multiparty politics meant that political issues were dealt with; what remain to be resolved are economic issues of Malawi. From 1994 to date, Malawi finds herself in a

118 Donald E. Gowan, Sermons for Broken Hearts: 1998 Berger Lectures (Dubuque: University Of Dubuque Theological Seminary, 1998), 34.

119 Barker and Bailey, Micah, 375.

${ }^{120}$ Greg Woolf, "Imperialism, Empire and the Integration of the Roman Economy," World Archaeology 23, no. 3 (1992), 283.

${ }^{121}$ Boer, "Sacred Economy," 38. 
crisis moment where economies of extraction pose as a new challenge to the country. Since the onset of multiparty, poverty has increased even as the politics of Malawi have assumed a 1980s "West African" pattern of increased corruption, personality based parties and a failing economy. ${ }^{122}$ In the context of Malawi, political elites have become internal oppressors, while international financial institutions and some western country through their bad economic policies have turned out to be external imperial oppressors.

By virtue of their position and power, Malawian elites have become mediations between despotic empire and poor Malawians. As internal and external imperial powers, the two have worked jointly in creating numerous socio-economic problems through extraction of Malawi's only resources which were meant to benefit the poor. Although Sampie Terreblanche is describing the South African situation, his analysis assists in understanding economic dimensions of Malawi.

The politico-economic system that has replaced white political domination and colonial and racial capitalism is a liberal capitalist version of democratic capitalism that can best be described as a system of African elite democracy cum capitalist enclavity. A new symbiotic relationship has been forged between the mainly white corporate elite and the black governing elite in which the former is very much the senior partner and the latter very much the junior and dependent partner. ${ }^{123}$

Translating this into Malawian context, we can say that the colonial rule and one party rule were replaced by politico-economic system that is run by group of elites who are corrupt. These are the people who, when they find their way into power, they try all means to extract from government resources. In Africa, the distinction between public and private has been hardly recognised, and public office has been accepted as a route to personal wealth and power. ${ }^{124}$ Thus, Gifford calls this "The politics of the belly" because officials tend to exercise their powers as a form not of public service but of private property.

The other contributing factor to the Malawi economic crisis is the fact that from birth Malawi has been essentially an agency of control and extraction. ${ }^{125}$ When African countries became independent, Africa shared in both the economic boom and the resultant social transformation, which meant that Africa came to independence on a surge of optimism, even euphoria. ${ }^{126}$ Gifford

122 Lwanda, Music, 7.

123 Sampie Terreblanche, A History of Inequality in South Africa 1652-2002 (Pietermaritzburg: University of Natal Press, 2002), 423.

124 Gifford, African Christianity, 5.

125 Gifford, African Christianity, 4.

126 Gifford, African Christianity, 4. 
says the euphoria did not last long because of some political systems that took root in Africa. He says:

Colonial states had been above all about control: they were essentially about securing the obedience of alien people. They were hierarchical, with their primary aim being the maintenance of order. Moreover, as the colonial states had to pay for themselves, they were geared to extracting resources from the domestic economy, or from the trade flowing from the economy's incorporation into the global trading system.", 127

Saul labels this neo-colonialism where freshly liberated African states were met by new economic forms of imperialism that focused on extracting from these states. ${ }^{128}$ Gifford speaks of this as neo-patrimonialism based on the kind of authority a father has over his children. ${ }^{129}$ He says that those lower in the hierarchy are not subordinate officials with defined powers and functions of their own, but retainers whose position depends on a leader to whom they owe allegiance. ${ }^{130}$ It was through this kind of partnership that forms of capitalism found their way into Africa states. Those higher in the hierarchy, namely, institutions such as World Bank, International Monetary Fund and some western countries, would always impose structural adjustments not to help but to extract from these already poor countries. So, they come into the Malawian context to extract. Imperial powers will provide services such as security, building roads, mines etcetera with an intention of extracting from the very same people they are serving. ${ }^{131}$

The role played by external oppressors in Malawi need not be underrated; it is the imposition of economic and political adjustments on the internal operations that compel the elite in Malawi to tyrannise their own subjects while benefiting from the system. The systemic relationship between external and internal oppressors rests on the fact that Malawi's internal dimensions are always controlled by the imposing power. We observe that most imperial powers and international financial institutions have all mechanisms of monitoring Malawi's economy to the extent that internal politics will follow whatever is laid before her. These foreign institutions have abilities to twist poor countries into any direction because they have direct control over the economy. This has serious repercussions on the lives of the poor; economy plays a crucial role in their lives because it is the driving force behind how people produce and reproduce their lives.

127 Gifford, African Christianity, 4.

128 Saul, Decolonization and Empire, 41.

129 Gifford, African Christianity, 5.

${ }^{130}$ Gifford, African Christianity, 5.

131 Gifford, African Christianity, 6. 


\section{CONCLUSION}

Habakkuk spoke against all, in every generation: who conquer by unholy ambition, greed and covetousness, who build their kingdom by violence, cruelty and bloodshed, and taking advantage of the weak (Hab 2:6-20). His relevance lies not just in his religious and social message, but also in condemnation of the greed and cruelty of imperialism and his creation of a spiritual alternative. ${ }^{132}$ Therefore, the idea of this study is not just to "understand" the role of the wicked in Habakkuk, but it is meant to challenge the Malawi socio-economic and political situation. This implies that we should not be satisfied with simply exposing imperial tendencies in canonical texts and deconstructing them, but should go further to construct interpretations which have decolonising effects in the contemporary world. ${ }^{133}$ Our task today is no longer to fight for political liberation but to fight for freedom from the control of economies. ${ }^{134}$ Malawi realised her political independence in 1964, what is required now is to achieve a just measure of economic independence and non-exploitative global relationships.

\section{BIBLIOGRAPHY}

Aberbach, David. Imperialism \& Biblical Prophecy 750 - 500 B.C.E. New York: Routledge, 1993.

Achtemeier, Elizabeth. Nahum - Malachi. Interpretation: A Bible Commentary for Teaching and Preaching. Atlanta: John Knox Press, 1986.

Ahlstrom, Gösta W. Royal Administration and National Religion in Ancient Palestine. Leiden: E. J. Brill, 1982.

Andersen, Francis I. Habakkuk: A New Translation with Introduction and Commentary. New York: The Anchor Bible Doubleday, 2001.

Baker, David W. Nahum, Habakkuk, Zephaniah: An Introduction and Commentary. Downers Grove, Ill.: Inter-Varsity Press, 1988.

Barker, Kenneth L. and Waylon Bailey. Micah, Nahum, Habakkuk, Zephaniah. The New American Commentary 20. Nashville: Broadman \& Holman Publishers, 1999.

Boer, Roland. "The Sacred Economy of Ancient 'Israel." Scandinavian Journal of the Old Testament 21/1 (2007): 29-48.

Bruce, Frederick Fyvie. "Habakkuk." Pages 831-896 in The Minor Prophets: An Exegetical and Expository Commentary. Volume 2. Edited by Thomas E. McComiskey. Grand Rapids, Mich.: Baker Books, 1993.

Dempsey, Carol J. The Prophets: A Liberation-Critical Reading. Minneapolis: Fortress Press, 2000.

Dube, Musa W. "Reading for Decolonization (John 4:1-42)." Semeia 75 (1996): 37 59.

132 Aberbach, Imperialism, 14.

133 Rasiah S. Sugirtharajah, ed. The Postcolonial Biblical Reader (Oxford, UK:

Blackwell Publishing,2006), 67.

${ }^{134}$ Sugirtharajah, Exploring, 134. 
Dube, Musa W. "Toward a Post-Colonial Feminist Interpretation of the Bible." Semeia 78 (1997): 11-26.

Freeman, Hobart E. An Introduction to the Old Testament Prophets. Chicago: Moody Press 1968.

Gifford, Paul. African Christianity: Its Public Role. London: Hurst \& Company, 1998.

Gottwald, Norman K. "Early Israel and the Canaanite Socio-Economic System." Pages 25-37 in Palestine in Transition: The Emergence of Ancient Israel. Edited by David N. Freedman and David F. Graf. Sheffield: The Almond Press, 1983. . "From Tribal Existence to Empire: The Socio-Historical Content for the Rise of the Hebrew Prophets." Pages 11-29 in God and Capitalism: A Prophetic Critique of Market Economy. Edited by J. Mark Thomas and Vern Visick. Madison, Wis.: A-R Editions, Inc., 1991. . The Politics of Ancient Israel. Louisville, Ky.: Westminster John Knox Press, 2001. . The Tribes of Yahweh: A Sociology of the Religion of Liberated Israel, 1250-1050 B.C.E. Maryknoll, N.Y.: SCM Press Ltd., 1979.

Gowan, Donald E. Sermons for Broken Hearts. 1998 Berger Lectures. Dubuque IW: University Of Dubuque Theological Seminary, 1998. . Theology of the Prophetic Books: The Death \& Resurrection of Israel. Louisville, Ky.: Westminster John Knox Press, 1998. . The Triumph of Faith in Habakkuk. Atlanta: John Know Press, 1976.

Leggett, Donald A. Loving God and Disturbing Men: Preaching from the Prophets. Grand Rapids: Baker Book House, 1990.

Lwanda, John L. C. Kamuzu Banda of Malawi: A Study in Promise, Power and Legacy (Malawi under Dr Hastings Kamuzu Banda (1961-1994). Zomba: Kachere Series, 2009. . Music, Culture and Orature: Reading the Malawi Public Sphere, 19492006. Zomba: Kachere Series, 2008.

Mason, Rex. Zephaniah, Habakkuk, Joel: Old Testament Guides. England: Sheffield Academic Press, 1994.

McCracken, John. A History of Malawi 1859-1966. Woodbridge: James Currey, 2012.

Moore, Stephen D. and Fernando F. Segovia, ed. Postcolonial Biblical Criticism: Interdisciplinary Intersections. Edited by Rasiah S. Sugirtharajah. London: T\&T Clark International, 2005.

Phiri, Desmond D. History of Malawi. Volume 2. Blantyre: College Publishing Company (Pvt) Ltd, 2010.

Pinker, Aron. "Habakkuk 2.4: An Ethical Paradigm or a Political Observation?" Journal for the Study of the Old Testament 32/1 (2007): 91-112. . Habakkuk: A Commentary: Unpublished manuscript, 2015.

Ross, Kenneth R. "The Transformation of Power in Malawi 1992-95: The Role of the Christian Church." The Ecumenical Review 48/1 (1996): 38-52.

Saul, John S. Decolonization and Empire: Contesting the Rhetoric and Practice of Resubordination in Southern Africa and Beyond. Johannesburg: Wits University Press, 2008.

Smith, George A. The Book of the Twelve Prophets, Vol. 2. New York: Harper \& Brothers Publishers, 1899.

Snell, Daniel C. Life in the Ancient Near East, 3100-332 B.C.E. New Haven: Yale University Press, 1997. 
Steeger, William P. “A Socio-Historical Examination of Habakkuk 1-2.” Ph.D. diss., Southern Baptist Seminary, 1983.

Sugirtharajah, Rasiah S. Exploring Postcolonial Biblical Criticism: History, Method, Practice. Chichester: Wiley-Blackwell, 2012. , ed. The Postcolonial Biblical Reader. Oxford: Blackwell Publishing, 2006.

Sweeney, Marvin A. The Twelve Prophets. Volume 2. Berit Olam: Studies in Hebrew Narrative \& Poetry. Collegeville, Minn.: The Liturgy Press, 2000.

Szeles, Maria E. Wrath and Mercy: A Commentary on the Books of Habakkuk and Zephaniah. Grand Rapids: Wm. B. Eerdmans Publishing Company, 1987.

Tengatenga, James. "Seek His Kingdom and His Righteousness and All Things Will be Given to You," (Unpublished manuscript, 2001).

Terreblanche, Sampie. A History of Inequality in South Africa 1652-2002. Pietermaritzburg: University of Natal Press, 2002.

Thomas, J. Mark. “The Quest for Economic Justice.” Pages 1-10 in God and Capitalism: A Prophetic Critique of Market Economy. Edited by J. Mark Thomas and Vern Visick. Madison, Wis.: A-R Editions, Inc., 1991.

Van De Mieroop, Marc. A History of the Ancient Near East ca. 3000-323 BC. 2nd ed. Malden: Blackwell Publishing, 2007.

Wagner-Tsukamoto, Sigmund. "State Formation in the Hebrew Bible: An Institutional Economic Perspective." Journal for the Study of the Old Testament 37/4 (2013): $391-422$

West, Gerald O. "Tracking an Ancient Near Eastern Economic System: The Tributary Mode of Production and the Temple-State." Old Testament Essays 24/2 (2011): 511-32.

. Biblical Hermeneutics of Liberation: Modes of Reading the Bible in the South African Context. 2nd rev. ed. Pietermaritzburg: Cluster Publications, 1995. . Contextual Bible Study. Pietermaritzburg: Cluster Publications, 1993. . "Doing Postcolonial Biblical Interpretation @ Home: Ten Years of (South) African Ambivalence." Neotestamentica 42/1 (2008): 147-64.

Woolf, Greg. "Imperialism, Empire and the Integration of the Roman Economy." World Archaeology 23/3 (1992): 283-93.

Rev. Takuze Saul Chitsulo, Scottsville Presbyterian Church, 2 Carbis Road, Scottsville, Pietermaritzburg, 3209. Email: tbchitsulo@yahoo.com. 